\title{
HUBUNGAN PERNIKAHAN USIA DINI DAN POLA ASUH BADUTA (0- 23 BULAN) TERHADAP KEJADIAN STUNTING
}

\author{
1'Zulhakim, ${ }^{2}$ Suryo Ediyono, ${ }^{3}$ Heni Nur Kusumawati \\ 1Universitas Nahdlatul Ulama NTB \\ 2Universitas Sebelas Maret Surakarta \\ ${ }^{3}$ Politeknik Kesehatan Kemenkes Surakarta \\ e-mail: jzulhakim@gmail.com
}

\begin{abstract}
ABSTRAK
Pernikahan usia dini $<20$ tahun dapat mempengaruhi status gizi anak yang dilahirkan. Ibu yang menikah di usia dini, status gizi anak berisiko mengalami kekurangan gizi, kurus dan gizi buruk. Tujuan untuk mengetahui hubungan pernikahan dini dan pola asuh bayi usia dua tahun (0-23 bulan) dengan kejadian stunting.Penelitian ini merupakan penelitian observasional dengan desain potong lintang terhadap 82 orang bayi usia dua tahun usia 0-23 bulan dari ibu belum menikah usia dini. Ibu mengatakan menikah usia dini bila usia ibu saat menikah $<20$ tahun. Status gizi bayi usia dua tahun diperoleh dari z-score $\mathrm{PB} / \mathrm{U}$, analisis data menggunakan uji Chi-square. Hasil tersebut menunjukkan bahwa sebanyak $73,2 \%$ wanita usia 18-20 tahun sudah menikah, sedangkan usia 15-17 tahun sebanyak $26,8 \%$. Persentase stunting bayi usia dua tahun dari ibu yang belum menikah usia 15-17 tahun sebanyak 36,4\%, sedangkan pada kelompok usia 18-20 tahun yang menikah sebanyak $41,7 \%$ bayi usia dua tahun yang stunting. Hal ini menunjukkan tidak ada hubungan antara ibu menikah usia dini dengan kejadian stunting pada bayi usia 2 tahun usia $0-23$ bulan $(\mathrm{p}=0,664)$. Persentase hasil pola asuh ibu yang baik sebanyak $30,4 \%$, dengan kejadian stunting dan pola asuh ibu yang tidak baik sebanyak $61,5 \%$ dengan kejadian stunting. Dengan demikian hasil penelitian ini menunjukkan hubungan yang signifikan $\mathrm{p}=(\mathrm{P}<0,05)$ antara pola asuh ibu dengan kejadian stunting. Tidak ada hubungan yang bermakna antara pernikahan dini dengan kejadian stunting $(\mathrm{P}=0.664)$.
\end{abstract}

Kata kunci: pernikahan usia dini; pengasuhan anak; stunting

\section{ABSTRACT}

Marriage early age <20 years can affect the nutritional status of children born. Mothers who get married at an early age, nutritional status of children at risk of having a short, skinny nutrition and malnutrition. The aim to determine the relationship of early marriage and parenting two year old baby ( 0 - 23 months) and the incidence ofstunting. This study was an observational study using cross-sectional design of the 82 people two year old baby aged 0-23 months of unmarried mothers early age. Mom said to get married early age when maternal age at married <20 years. Two year old baby nutritional status obtained from the z-score $P B / U$, data analysis using Chi-square test. These results indicate that as many as 73.2\% of women aged 18-20 years were married, while the 15-17 age as much as 26.8\%. Two year old baby stunting percentage of unmarried mothers early age 15-17 as much as 36.4\%, while in the age group 18-20 years were married as much as $41.7 \%$ two year old baby that stunting. This shows there is no relationship between mother married an early age on the incidence of stunting in two year old baby aged 0-23 months $(p=0.664)$. Percentage yield good mother parenting as much as $30.4 \%$, with the incidence of stunting and parenting are not good mothers as much as $61.5 \%$ in the incidence ofstunting. Thust he results oft his study showed asignificant relationship $=(P<0.05)$ between maternal parenting style with the 
incidence of stunting. There is no significant relationship between early marriage with the incidence of stunting $(P=0.664)$.

Keywords: early agemarriage, parenting, stunting

\section{PENDAHULUAN}

Stunting merupakan suatu kondisi malnutrisi yang ditandai dengan nilai $\mathrm{Z}$ score tinggi badan menurut umur di bawah -2 SD. Tingginya prevalensi stunting pada balita menunjukkan terganggunya kualitas pertumbuhan pada masa emas (Laksono \& Kusrini, 2017). Masalah pendek (stunting) pada anak akan menghambat perkembangan, dampak negative ini akan berlanjut dalam kehidupan setelahnya. Hal ini dikarena sekitar $70 \%$ pembentukan sel otak terjadi sejak janin masih dalam kandungan hingga anak berumur 2 tahun (Depkes, 2012).

Tahun 2017, sekitar setengah dari semua anak yang mengalami stunting tinggal di Asia dan lebih dari sepertiga di afrika (United Nations Children's Fund, Word Health Organization and World Bank group, 2018). Indonesia menempati urutan ke-5 di dunia, 5 juta dari 12 juta balita $(38,65 \%)$ di Indonesia memiliki tinggi badan di bawah rata-rata tinggi badan balita di dunia kejadian balita pendek (stunting). Data Riset Kesehatan Dasar (Riskesdas) tahun 2013 memperlihatkan bahwa status gizi balita pendek di Indonesia adalah 37,2\%. Persentase tersebut relatif tidak menunjukkan perbaikan jika dibandingkan dengan data Riskesdas tahun 2010 (35,6\%) dan tahun 2007 (36,8\%) (Departemen Kesehatan RI, 2008; Kementerian Kesehatan RI, 2013). Riskesdas 2018 di beberapa provinsi di Indonesia terutama dikawasan timur Indonesia salah satunya adalah Provinsi Nusa Tenggara Barat memiliki proporsi stunting $25,15 \%$, ini menunjukkan angka kejadian stunting yang masih tinggi yang diartikan masih menjadi masalah kesehatan masyarakat yang serius menurut klasifikasi WHO karena prevalensi stunting $\geq 40 \%$, sedangkan untuk wilayah kerja puskesmas mantang, prevalensi stunting usia 0-23 bulan pada tahun 2018 mencapai 36,5\% (Dikes, 2018). Hal ini menunjukkan bahwa stunting merupakan permasalahan kesehatan masyarakat di Indonesia hingga saat ini (Kusrini \& Laksono, 2017).

Pernikahan adalah ikatan lahir dan batin antara seorang pria dengan seorang wanita sebagai suami-istri dengan tujuan membentuk keluarga yang sejahtera. Usia perkawinan yang ideal dilakukan oleh seorang laki-laki dengan usia minimal 25 tahun dan usia minimal wanita 20tahun, itu idealnya untuk menikah diperlukan persiapan, baik sehat secara fisik termasuk rahimnya juga siap (BKKBN, 2012). Jumlah wanita muda berusia yang menikah lebih besar jika dibandingkan dengan laki-laki yaitu $11,7 \%$ wanita muda berusia 15-19 tahun dan 6\% laki-laki berusia 15-19 tahun (Riskesdas, 2010). Menurut Khusna \& Nuryanto, (2017) persentase anak pendek meningkat pada ibu yang menikah di usia dini, semakin muda usia pernikahan ibu, maka proporsi balita dengan status gizi pendek semakin meningkat.

Pernikahan usia dini dapat berdampak buruk terhadap kesehatan ibu dan balita. Faktor yang menyebabkan adalah organ reproduksi pada ibu yang belum siap, tingkat pendidikan ibu, pengetahuan yang kurang, dan perawatan ibu ketika hamil. Anak yang lahir dari ibu yang menikah usia dini memiliki kesempatan hidup yang rendah dan lebih besar memiliki masalah gizi seperti pendek, kurus, dan gizi buruk. Hal tersebut kemungkinan bisa terjadi karena ibu balita yang umurnya kurang dari 18 tahun biasanya memiliki pola asuh terhadap anaknya kurang baik, pola asuh yang kurang baik tersebut dapat berdampak pada status gizi anaknya (BKKBN, 2012).

Proporsi perkawinan usia dini di Indonesia masih tinggi yakni $46,7 \%$ dari total perkawinan. Di Provinsi Nusa Tenggara Barat (NTB), kondisi perkawinan usia anak ini menunjukkan trend cukup tinggi. Menurut survei nasional. NTB berada pada urutan tertinggi dalam kasus perkawinan anak. Bahkan menurut Dinas Pemberdayaan Perempuan Perlindungan Anak dan Keluarga Berencana (DP3AKB) NTB setengah dari penduduk NTB melakukan perkawinan anak. Pada tahun 2014, persentase perkawinan anak mencapai 51,8\%, sedangkan tahun 2015 mencapai $34,9 \%$. Menurut data kabupaten rekor tertinggi dipegang oleh kabupaten 
Lombok Timur dan Lombok Tengah, dengan angka $67,15 \%$ dan $63,28 \%$, sedangkan menurut data pernikahan yang ada di wilayah kerja puskesmas mantang (Desa Presak, Bujak, Mantang, Barabali dan Tp Siring) pada tahun 2018, hasil survei pada perempuan berumur 16-19 tahun diketahui prevalensinya $31,92 \%$. Rata-rata tingkat pendidikan mereka yang melakukan perkawinan anak adalah remaja tamatan SMP-SMA (KUA Batukeliang, 2018)

Pola asuh adalah praktik di rumah tangga yang dilihat dengan tersedianya pangan dan perawatan kesehatan serta sumber lainnya untuk kepentingan hidup, pertumbuhan dan perkembangan (Zeitlin, 2000). Menurut (Al Kahfi, 2015) pola asuh terdiri dari pemberian IMD, pemberian ASI dan MP-ASI, praktik higiene atau sanitasi lingkungan. Pola asuh merupakan salah satu faktor yang berkaitan dengan stunting. (Picauly \& Toy, 2013) menunjukkan bahwa ibu dengan pola asuh yang kurang atau rendah memiliki peluang lebih besar anaknya terkena stunting dibandingkan ibu dengan pola asuh baik.

Renyoet dkk (2013) tentang hubungan pola asuh dengan kejadian stunting, menunjukkan bahwa pemberian ASI eksklusif, MP-ASI, praktik pemberian makan, higene dan sanitasi lingkungan, serta pemanfaatan layanan kesehatan memiliki pengaruh yang signifikan terhadap kejadian stunting pada balita. Sementara itu, penelitian Arifin dkk (2012) tentang analisis sebaran dan penyebab stunting menunjukkan pemberian ASI eksklusif mempunyai hubungan yang signifikan dan merupakan faktor paling dominan terhadap kejadian stunting. Berat Badan Lahir Rendah (BBLR) merupakan salah satu faktor yang dapat mempengaruhi kejadian stunting, karena seringkali terjadi pada masa pertumbuhan janin terutama pada ibu yang belum cukup umur dan kekurangan gizi selama masa kehamilan (Bappenas, 2013). Penelitian Candra dkk (2011), menunjukkan bahwa BBLR merupakan salah satu faktor yang paling berpengaruh terhadap kejadian stunting selain tinggi ayah dan riwayat berat badan rendah.

Berdasarkan uraian tersebut penulis tertarik menganalisis "Hubungan Pernikahan Usia Dini dan Pola Asuh Baduta 0-23 Bulan Terhadap Kejadian Stunting di Wilayah Kerja Puskesmas Mantang Kecamatan Batukliang, Kabupaten Lombok Tengah”.

\section{METODE PENELITIAN}

Jenis penelitian yang digunakan dalam penelitian ini adalah penelitian observasional dengan menggunakan rancangan CrossSectional. Penelitian ini telah dilaksanakan di wilayah kerja Puskesmas Mantang Kabupaten Lombok Tengah pada bulan November sampai dengan Desember tahun 2019. Populasi dalam penelitian ini adalah seluruh baduta berusia 0-23 bulan yang ibunya menikah usia < 20 tahun yang berada di wilayah kerja Puskesmas Mantang Kabupaten Lombok Tengah sebanyak 82 orang. Sampel pada penelitian ini sejumlah 82 orang yang memiliki baduta berusia 0-23 bulan dengan kriteria sebagai berikut:

a. Kriteria inklusi:

1) Usia ibu menikah < 20tahun

2) Bertempat tinggal di wilayah Kerja Puskesmas Mantang

3) Ibu dan baduta (0-23 bulan) bertempat tinggal

5) pada rumah yang sama

6) Usia responden pengambilan sampel kurang dari $<20$ tahun

7) Ibu baduta bersedia sebagai responden penelitian dengan mengisi informed consent

8) Keluarga tidak lengkap

b. Kriteria eksklusi:

Usia saat menikah lebih dari atau sama dengan 20 tahun

1) Bertempat tinggal di luar wilayah Puskesmas Mantang

2) Anak di asuh oleh orang lain / tidak diasuh oleh ibu kandungnya

Bahan dan alat yag digunakan dalam penelitian ini adalah alat dan bahan diantaranya

1. Timbangan dacin atau timbangan digital yang digunakan untuk menimbang berat badan baduta

2. Infantometer digunakan untuk mengukur panjang badan baduta

3. Analisis univariat digunakan untuk menggambarkan karakteristik subjek penelitian dengan menghitung distribusi frekuensi dan proporsi masing-masing variabel, selanjutnya data ditampilkan dalam bentuk tabel dan narasi. Analisis bivariat dilakukan dengan uji Chi-square untuk mengetahui ada atau tidaknya hubungan antara variabel bebas dan variabel terikat yaitu hubungan pernikahan usia dini dan pola asuh baduta 0-23 bulan dengan kejadian stunting 


\section{HASIL DAN PEMBAHASAN}

a. Hubungan Antar Variabel Tabulasi Silang AntaraPenelitian

Hubungan pernikahan usia dini dengan kejadian stunting di wilayah kerja
UPTD Puskesmas Mantang Kecamatan Batukliang Kabupaten Lombok Tengah

Tabel 1 Hasil Uji Chi-Square (Hubungan Pernikahan Usia Dini dengan Kejadian Stunting

\section{Klasifikasi Status Gizi PB/U}

\begin{tabular}{|c|c|c|c|c|c|}
\hline \multirow{2}{*}{$\begin{array}{l}\text { Usia Pernikahan Dini } \\
\text { Stunting }\end{array}$} & \multicolumn{2}{|c|}{ Stunting } & \multicolumn{2}{|c|}{ Tidak } & \multirow[t]{2}{*}{$P$} \\
\hline & $\mathbf{n}$ & $\%$ & $n$ & $\%$ & \\
\hline $18-20$ & 25 & 41,7 & 35 & 42,7 & 0,664 \\
\hline $15-17$ & 8 & 36,4 & 14 & 63,6 & \\
\hline Total & 33 & 40,2 & 49 & 59,8 & \\
\hline
\end{tabular}

Sumber: Data Primer 2019

Berdasarkan Tabel 4.11 menunjukkan bahwa usia pernikahan dini pada usia $\geq 18$ tahun dengan kategori stunting sebanyak 25 baduta $(41,7 \%)$ dan 35 baduta $(42,7 \%)$ yang tidak stunting. Dari usia $<18$ tahun telah memiliki 8 baduta $(36,4 \%)$ yang mengalami stunting dan 14 baduta $(63,6 \%)$ tidak stunting. Berdasarkan hasil uji statistik menggunakan chi square diperoleh nilai uji $p=0,664>0,05$ hal tersebut menunjukkan bahwa $\mathrm{Ha}$ ditolak dan $\mathrm{Ho}$ diterima. Hal tersebut dapat disimpulkan bahwa tidak terdapat hubungan antara usia menikah usia dini terhadap kejadian stunting.

Berdasarkan hasil penelitian di wilayah kerja UPTD Puskesmas Mantang. Penelitian ini menunjukkan rerata usia ibu saat menikah dini mulai usia 20 tahun kebawah atau 41 responden $(50 \%)$ dimana menurut UU Nomor 1 Tahun 1974 tentang perkawinan, pada pasal 7 ayat (1), yaitu perkawinan hanya diijinkan jika pihak pria sudah mencapai umur 19 tahun dan pihak wanita sudah mencapai umur 16 tahun. Pada pasal 6 ayat (2) juga disebutkan untuk melangsungkan perkawinan seorang yang belum mencapai pada umur 21 tahun harus mendapat izin kedua orang tua.

Menurut WHO, stunting merupakan kondisi dimana balita memiliki panjang atau tinggi badan yang kurang jika dibandingkan dengan usia. Masalah baduta pendek (stunting) menggambarkan adanya masalah gizi kronis, dipengaruhi dari kondisi ibu atau calon ibu, masa janin, masa bayi atau balita, termasuk penyakit yang diderita selama masa balita (Larasati dkk, 2018)

Hasil penelitian uji statistik menggunakan uji chi-square diperoleh dari nilai $p=0,664>$ 0,05, OR (Odds Ration) 0,456 (95\% CI), hal tersebut menandakan bahwa pernikahan usia dini tidak memiliki faktor resiko 0,456 dengan kejadian stunting pada baduta di wilayah kerja UPTD Puskesmas Mantang Kecamatan Batukliang Kabupaten Lombok Tengah.

Hasil penelitian ini sejalan dengan yang dilakukan oleh Khairunnisa (2020) bahwa hasil hitung uji statistika menggunakan Spearman"s rho diperoleh hasil $p=0,160$ $>0,05$ maka ini menunjukkan bahwa $\mathrm{Ha}$ ditolak dan Ho diterima, yang artinya dapat disimpulkan bahwa tidak ada hubungan usia menikah remaja dengan kategori stunting.

Hal ini juga sejalan dengan penelitian sebelumnya walaupun berbeda variabel yang dilakukan oleh Khusna dan Nuryanto (2017), penelitian tersebut menunjukkan bahwa tidak ada hubungan yang signifikan usia ibu menikah dini dengan status gizi batita dengan kesimpulan terdapat kecendrungan semakin dini usia ibu menikah, semakin meningkat persentase anak pendek dan gizi kurang, tetapi secara statistik tidak ada hubungan antara usia ibu menikah dini dengan status gizi baduta di Kabupaten Temanggung.

Ibu yang hamil di usia remaja masih dalam masa pertumbuhan sehingga dapat terjadi perebutan asupan gizi antara janin dan ibu itu sendiri. Perebutan asupan gizi tersebut akan semakin parah jika asupan gizi ibu tidak kuat 
sehingga janin akan mengalami terlambatnya perkembangan tubuh. Kejadian tersebut akan mengingatkan resiko janin lahir dengan berat badan lahir rendah, hal tersebut menjadi faktor terjadinya stunting pada baduta. Kehamilan di usia awal remaja, ketika ibu juga masih tumbuh akan meningkatkan resiko bayi yang dilahirkan akan menjadi stunting (Larasati dkk, 2018).

Untuk itu pada penelitian ini pernikahan usia remaja dapat menyebabkan stunting karena semua anak responden mengalami stunting dengan pernikahan usia remaja namun dengan kategori yang berbeda. Dengan hasil remaja yang menikah di usia $\geq 18$ tahun memiliki $56,7 \%$ yang mengalami stunting dan terdapat < 18 tahun memiliki 13,3\% yang mengalami stunting (Khairunnisa, 2020).

Kategori stunting baduta dengan tinggi badan berdasarkan usia tidak berhubungan dengan usia ibu menikah pada saat remaja karena pada penelitian ini usia ibu saat menikah pertama kali lebih banyak usia 18-20 tahun dengan anak pendek yang pada saat usia tersebut sudah terjadi proses matangnya organ reproduksi untuk kehamilan, sehingga apabila selama kehamilan pada usia 18-20 tahun tidak tercukupi gizinya dapat menyebabkan akan pendek (Khairunnisa, 2020).

Tabel 2. Hasil Uji Chi-Square (Hubungan Pola Asuh dengan Kejadian Stunting)

\begin{tabular}{|c|c|c|c|c|c|}
\hline \multirow{4}{*}{ PolaAsuh } & \multicolumn{4}{|c|}{ Klasifikasi Status Gizi PB/U } & \multirow{4}{*}{$P$} \\
\hline & \multirow{2}{*}{\multicolumn{2}{|c|}{$\begin{array}{l}\text { Stunting } \\
\text { stunting }\end{array}$}} & \multirow{2}{*}{\multicolumn{2}{|c|}{ Tidak }} & \\
\hline & & & & & \\
\hline & $\mathbf{n}$ & $\%$ & $\mathbf{n}$ & $\%$ & \\
\hline Baik & 17 & 30,4 & 39 & 69,6 & 0,007 \\
\hline Tidak baik & 16 & 61,5 & 10 & 38,5 & \\
\hline Total & 33 & 40,2 & 49 & 59,8 & \\
\hline
\end{tabular}

Sumber: Data Primer 2019

Berdasarkan Tabel 4.12 menunjukkan bahwa baduta yang mengalami stunting dari pola asuh dengan kategori baik berjumlah 17 baduta $(30,4 \%)$ dibandingkan dengan status gizi tidak stunting sebanyak $39(69,6 \%)$. Untuk baduta yang mengalami stunting dari pola asuh dengan kategori tidak baik berjumlah 16 baduta $(61,5 \%)$ dibandingkan dengan status gizi tidak stunting sebanyak 10 baduta $(38,5 \%)$. Jadi hasil penelitian ini menunjukkan adanya hubungan yang signifikan $p=0,007(p<0,05)$ antara pola asuh ibu dengan kejadian stunting.

Hasil penelitian uji statistik menggunakan uji chi-square diperoleh dari nilai $\mathrm{p}=0,007$ ( $\mathrm{p}<0,05)$, diperoleh OR (Odds Ration) 0,103 (95\% CI), hal tersebut menandakan bahwa pola asuh baduta dengan faktor resiko 0,103 kali dengan kejadian stunting.

Hasil penelitian ini sejalan dengan yang dilakukan oleh Amin AM, (2003) bahwa ada hubungan yang signifikan antara pola asuh dengan status gizi anak usia 6-24 bulan dimana pola asuh makan yang baik berdampak pada status gizi anak normal.
Praktek pemberian makan pada anak sangat penting dan besar pengaruhnya bagi pertumbuhan anak. Memberikan suasana yang nyaman bagi anak pada saat makan, mengetahui selera makan yang baik pada anak, sabar dan penuh perhatian pada saat memberikan makan tentu dapat menjalin keakraban diantara keduanya sehingga diharapkan anak mampu menghabiskan makanan yang diberikan.

Penelitian ini tidak sejalan dengan yang dilakukan Muniroh (2015) bahwa tingkat pendidikan ibu, tingkat pengetahuan ibu, dan pola asuh tidak berhubungan dengan kejadian stunting. Namun, ada faktor lain di luar faktor yang diteliti tersebut yang mempengaruhi kejadian wasting dan stunting. Banyak faktor yang mendukung terjadinya stunting pada anak. Kualitas asupan zat gizi serta paparan terhadap infeksi merupakan faktor utama penyebab gangguan pertumbuhan pada baduta. Menyusui, memberikan makan bergizi dan mengontrol besar porsi yang dihabiskan akan meningkatkan status gizi anak (Sawadogo, et al, 2015). 
Hasil penelitian ini sejalan dengan yang dilakukan oleh Rita dkk, (2019) terdapat hubungan antara riwayat pemberian ASI, waktu pemberian MP ASI, pemanfaatan pelayanan kesehatan, tingkat pengetahuan ibu, dan sanitasi lingkungan terhadap kejadian stunting di Kabupaten Lebong. Hasil penelitian ini sejalan dengan yang dilakukan oleh Larasati, (2018) menyatakan bahwa terdapat hubungan yang signifikan antara riwayat pemberian ASI eksklusif dengan kejadian stunting pada balita dengan nilai pvalue $=0,000(\mathrm{p}<0,005)$. Pada interval kepercayaan (CI) 95\%, nilai Odds Ratio (OR) yang dihitung $(3,23)$. Nilai Odds Ratio menunjukan bahwa balita yang tidak mendapatkan ASI secara eksklusif bere siko 3,23 lebih besar mengalami stunting dibandingkan dengan balita yang mendapatkan ASI secara eksklusif. Hasil dari analisis tersebut dapat dinyatakan bahwa pemberian ASI merupakan faktor resiko terhadap kejadian stunting pada balita.

Pemberian ASI eksklusif juga berkaitan dengan pemberian kolostrum (ASI yang pertama kali keluar). Anak yang tidak mendapatkan kolostrum memiliki status pertumbuhan yang lebih jelek dibandingkan anak yang diberikan kolostrum. Kondisi ini dikarenakan kekurangtahuan ibu balita tentang penting dan manfaat dari kolostrum bagi balita. Kolostrum banyak diyakini oleh ibu merupakan susu kotor yang harus dibuang karena warnanya tidak putih (Rita dkk, 2019)

Hasil penelitian ini sejalan dengan yang dilakukan oleh Larasati, (2014) menyatakan terdapat hubungan yang bermakna antara usia pemberian MP-ASI dengan status gizi anak usia 1-3 tahun di Kota Padang Tahun 2012 $(\mathrm{p}=0,001)$. Hubungan tersebut menunjukkan jika anak diberi MP-ASI sesuai jadwal akan menghasilkan tumbuh kembang anak yang lebih baik dari pada anak yang diberi MP-ASI dini. Hasil penelitian ini sejalan dengan yang dilakukan oleh Septiana dkk, (2010) menyatakan bahwa ada hubungan yang bermakna antara pola pemberian MP-ASI dan status gizi balita usia 6-24 Bulan di Puskesmas Gedongtengen Yogyakarta. Nilai $\mathrm{p}=0,043$ pada $\alpha=5 \%(0,043<0,05)$.

Anak balita yang diberikan ASI eksklusif dan MP-ASI sesuai dengan kebutuhnnya dapat mengurangi risiko terjadinya stunting. Hal ini karena pada usia 0-6 bulan pemberian ASI eksklusif akan menjadikan kekebalan tubuh anak balita meningkat sehingga dapat terhindar dari penyakit infeksi. Pada usia 6 bulan anak balita diberikan MP-ASI dalam jumlah dan frekuensi yang cukup sehingga terpenuhi kebutuhan zat gizinya yang dapat mengurangi risiko stunting. Diberikannya MP-ASI pada bayi sebelum waktunya termasuk dampak dari tidak diberikannya ASI eksklusif pada bayi. MP-ASI yang diberikan terlalu dini akan berdampak pada kurangnya selera makan bayi, sebaliknya pemberian MPASI yang terlambat menyebabkan bayi sulit menerima makanan pendamping (Rita dkk,2019).

Hasil penelitian ini sejalan dengan yang dilakukan oleh Septiana dkk, (2010) menyatakan bahwa ada hubungan yang signifikan antara sanitasi lingkungan dengan kejadian stunting $(\mathrm{p}=0,000)$ dengan nilai $\mathrm{OR}=$ 10,879. Dapat disimpulkan bahwa ibu balita yang memiliki sanitasi lingkungan yang kurang baik berisiko 10,879 kali lebih besar menyebabkan balita stunting dibandingkan ibu yang memiliki sanitasi lingkungan baik. Hasil penelitian melaporkan bahwa balita yang berasal dari keluarga yang memiliki sumber air minum tidak terlindung berisiko mengalami stunting sebesar 1,35 kali lebih besar dibandingkan dengan balita dari keluarga dengan sumber air minum terlindung. Kematian dan kesakitan pada anak-anak umumnya dikaitkan dengan sanitasi yang tidak memadai dan sumber air minum yang tercemar. Sumber air minum yang bersih merupakan factor penting untuk kesehatan tubuh dan mengurangi resiko serangan berbagai penyakit seperti diare kolera dan tipus (Rita dkk, 2019).

Ada banyak faktor yang menyebabkan terjadinya stunting, seperti faktor pendidikan ibu, dan ekonomi atau pendapatan. Pendidikan ibumerupakan hal dasar bagi tercapainya gizi balita yang baik. Tingkat pendidikan ibu tersebut terkait dengan kemudahan ibu dalam menerima informasi tentang gizi dan kesehatan dari luar, dibandingkan dengan ibu yang memiliki tingkat pendidikan rendah.

Dwi Astari (2005), menyatakan bahwa terdapat hubungan nyata $(\mathrm{p}=0.05)$ antara pengasuhan dengan sosial ekonomi keluarga yaitu pendidikan oran gtua dan pendapatan keluarga. Hal ini menunjukkan pendidikan orangtua akan mempengaruhi pengasuhan anak, karena orang tua dengan pendidikan yang lebih tinggi akan memahami betapa pentingnya peranan orang tua terhadap anak. Semakin tinggi pendidikan orang tua diduga 
semakin baik pengetahuan gizinya dan ibu yang memiliki pengetahuan gizi yang baik akan mengetahui tentang cara mengolah bahan makanan, cara mengatur menu dan mengatur makanan anak sehingga keadaan gizi anak terjamin. Selain itu diduga dengan pendapatan yang lebih besar akan memberikan pengasuhan yang lebih memadai dan menjamin kebutuhan yang diperlukan oleh anak seperti memenuhi kebutuhan gizi anak yang diperlukan untuk pertumbuhan, menyediakan lingkungan yang aman, mencegah dari penyakit dan melindungi dari paparan patogen.

Pendidikan orang tua dan pendapatan keluarga mempengaruhi pola pengasuhan orang tua terhadap anak. Pendidikan orang tua yang tinggi akan memiliki pengasuhan gizi yang diperlukan oleh anak. Pendapatan keluarga merupakan faktor penting dalam memberikan pengasuhan anak yang memadai dan menjamin kebutuhan yang diperlukan dalam pertumbuhan anak (Dwi Astari, 2005).

Hasil penelitian ini sejalan dengan yang dilakukan oleh Husein Al Anshori (2013), bahwa asupan zat gizi yang menjadi faktor risiko terjadinya stunting adalah asupan protein, sedangkan asupan energi dan zat gizi (karbohidrat, lemak, seng dan kalsium) bukan merupakan faktor risiko terjadinya stunting. Penelitian ini tidak sejalan dengan yang dilakukan oleh Dwi Puji khasanah dkk (2016), dari hasil uji analisis chi-square diperoleh nilai p-0,072 yang berarti tidak ada hubungan antara asupan protein dengan status gizi anak usia 6-23 bulan indeks panjang badan terhadap usia.

\section{KESIMPULAN}

a Tidak ada hubungan yang signifikan antara pernikahan usia dini dengan kejadian stunting $(\mathrm{p}=0,664)$

b. Ada hubungan yang signifikan antara pola asuh dengan kejadian stunting $(\mathrm{p}=0,00$ 


\section{REFERENSI}

Adriani, Merryana., \& Kartika, Vita. 2013. Pola Asuh Makan Pada Balita Dengan Status Gizi Kurang Di Jawa Timur, Jawa Tengah Dan Kalimantan Tengah Tahun, 2011. Jurnal Bulletin Penelitian System Kesehatan. Vol.16. No 2. April 2013 : 185-193

Afifah, T. Perkawinan Dini dan Dampak Dan Dampak Status Gizi. Gizi Indonesia. 2011;34(2):11

Arifin, D. Z., Indasari, S. Y., \& Sukandar, H. 2012. Analisis sebaran dan factor risiko stunting pada balita di kabupaten purwakarta. Epidemiologi komunitas FKUP. Diakes dari

http:/pustaka.unpad.ac.id/wpcontent/uploads /2013/07/pustaka_unpad_analisis_sebaran_d an_faktor_risik o_stunting.pdf

Auliana, Rizqie. 2011. Gizi seimbang dan makanan sehat untuk anak usia dini. Diakses dari

http://staff.uny.ac.id/sites/default/files/penga bdian/rizqie-auliana-dra-mkes/gizi-

seimbang-dan-makanan-sehat-untuk-anakusia- dini.pdf

Bappenas. 2013. 1000 Hari Pertama Kehidupan, Bulletin 1. Diakes dari http://www.bappenas.go.id/files/3213/8848/ 0645/buletin-1IND 1000HPK2013-10 03.pdf.

Cahyaningsih, C. T., Kushadiwijaya, H., Tholib, A. 2009. Hubungan Higiene Sanitasi Dan Perilaku Penjamah Makanan Dengan Kualitas Bakteriologis Peralatan Makan Di Warung Makan. Berita Kedokteran Masyarakat Vol. 25, No. 4, Desember 2009

Dikes. 2018. Laporan Baduta Stunting 0-23 Bulan Hasil Dines Kesehatan (Dikes). Puskesmas Mantang Kabupaten Lombok Tengah

Dwi, Puji Khasanah., dkk, 2016. Waktu Pemberian Makanan Pendamping ASI (MPASI) Berhubungan Dengan Kejadian Stunting Anak Usia 6-23 Bulan di Kecamatan Sedayu. Jurnal Gizi dan Dietetik Indonesia Vol. 4, No. 2, Mei 2016: 105-111

Engle, P. L., Menon, P., \& Haddad, L. (1997). Care And Nutrition : Concept and Measurement. International Food Policyresearch Institute

Ernawati, A. 2013. Hubungan Factor Social Ekonomi, Higiene Sanitasi Lingkungan,
Tingkat Konsumsi Dan Infeksi Dengan Status Gizi Anak Usia 2-5 Tahun Di Kabupaten Semarang Tahun 2003. Tesis. Program Pascasarjana Universitas Diponegoro

Farah, Okky Aridiyah., dkk. 2015. FaktorFaktor Yang Mempengaruhi Kejadian Stunting Pada Anak Balita di Wilayah Peesaan dan Perkotaan. Fakultas Kesehatan Masyarakat, Universitas jember. e-Jurnal Pustaka Kesehatan, vol.3 (no. 1) Januari 2015

Hidayat. T. S., \& Fuada, N. (2011). Hubungan Sanitasi Lingkungan, Morbiditas dan Status Gizi Balita di Indonesia. PGM 34(2), 34(2), 104-113

Kahfi, Al. 2015. Gambaran Pola Asuh Pada Baduta Stunting Usia 13-24 Bulan di Wilayah Kerja Pukesmas Neglasari Kota Tangerang Tahun 2015. Skripsi. Fakultas Kedokteran dan Ilmu Kesehatan Universitas Islam Negeri Syarif Hidayatullah

Kemenkes Kesehatan RI. Ditjen Bina dan Kesehatan Ibu dan Anak (2013).

Dengan Kategori Stunting. Jurnal Darul Azhar Vol 9, No.1 Februari 2020- Juli 2020 : 40-48

Khomsan, A., \&\& Ridhayani, S. (2008). Menu Sehat Untuk Tumbuh Kembang Anak Usia 624 Bulan. Jakarta: PT Agro Media Pustaka

Krisnatuti, D., Syarief, H., Soekirman, H., \& Saefuddin, A. (2006). Analisis Status Gizi Anak Usia Bawah Dua Tahun (Baduta) Pada Program Jarring Pengaman Social Bidang Kesehatan. Media Gizi Dan Keluarga, 30(1), Juli 2006, 1-14

Larasati, Dwi Agista., Nindya, Triska Susila., \& Arief, Yuni Sufyanti. 2018. Hubungan Antara Kehamilan Remaja Dan Riwayat Pemberian ASI Dengan Kejadian Stunting Pada Balita di Wilayah Kerja Puskesmas Pujon Kabupaten Malang. DOI: 10.2473/amnt.v2i4.2018.392-401

Machfoedz. Metode Penelitian (Kuantitatif Dan Kualitatif). Yogyakarta : Fitrayama; 2014.

Marmi. 2014. Gizi Dalam Kesehatan Reproduksi. Pustaka Pelajar

National Institute of Health Research and Development of Ministry of Health of The Republic of Indonesia (2019) The 2018 Indonesia Basic Health Survey (Riskesdas): National Report. Jakarta

Nency, Y., \& Arifin, M, T. 2005. Gizi Buruk Ancaman Generasi Yang Hilang.

Vol.5/XVII/November 2005, vol.5/XVII(ISSN : 
2085-871X).

Nisa, F, Z., (2013). Pola Asuh Anak Salah Akibatkan Gizi Buruk. Penyampaian Dilakukan Dalam Menyongsong Diselenggarakannya Simposium Internasional "Wellness, Healthy Lifestyle And Nutrition"

Notoadmodjo, S. Metode Penelitian Kesehatan. Jakarta : Rineka Cipta; 2010

Picauly, Intje., \& Toy, Sarci Magdalena. 2013. Analisis Diterminan Dan Pengaruh Stunting Terhadap Prestasi Belajar Anak Sekolah DiKupangDan Sumbawa Timur NTT. Jurnal Gizi Dan Pangan. Vol .8. No.1. Maret 2013, 8 (1) : 55-62

Permenkes RI. 2019. Angka Kecukupan Gizi. No. 28. Tahun 2019

Rahayu, Lestari Sari. 2011. Hubungan Pendidikan Orang Tua Dengan Perubahan Status Stunting Dan Usia 6-24 Bulan Ke Usia 3-4 Tahun. Proseding Penelitian Bidang Ilmu Ekstra 2011

Riset Kesehatan Dasar (2010). Laporan Hasil Riset Kesehatan Dasar 2013.

Sab"atmaja, S., Khomsan, A., \& Tanziha, I. (2010). Analisis Determinan Positive Deviance Status Gizi Balita Di Wilayah Miskin Dengan Prevalensi Kurang Gizi Rendah dan Tinggi. Jurnal Gizi dan Pangan, Juli 20105 (2): 103-112,

Sandy, S., Sumarni, S., \& Soeyoko. 2015. Analisis Model Faktor Risiko Yang Mempengaruhi Infeksi Kecacingan yang Ditularkan Melalui Tanah Pada Siswa Sekolah Dasar Di Distrik Arso Kabupaten Keerom Papua. Media Litbangkes. Vol. 25, No. 1, Maret 2015

Soetardjo, Susirah. 2011. Gizi Seimbang Dalam Daur Kehidupan: Gizi Anak.

Jakarta: PT Gramedia Pustaks Utama

Sugiyono. Metode Penelitian Kuantitatif Kualitatif dan $R \& D$. Bandung: Alfabeta.;2011

Susilowati., \& Kuspriyanto. 2016. Gizi Dalam Daur Kehidupan. PT Retika Aditama

Ulfani, D. H., martianto, D., Baliwati, Y. F. 201. Factor-Faktor Social Ekonomi Dan Kesehatan Masyarakat Kaitannya Dengan Masalah Gizi Underweight, Stunted, Dan Wasted Di Indonesia: Pendekatan Ekologi Gizi. Jurnal Gizi Dan Pangan, 2011, 6(1): 59-65

UNICEF. Really Simple Stats: the UNICEF Ghana Internal Statistical Bulletin.
In: UNICEF, editor : UNICEF; 2015

United Nations Children"s Fund, World Health Organization and World Bank Group (2018) Levels and trends in child malnutrition. UNICEF/WHO/ World Bank Group Joint Child Malnutrition Estimates Key findings of the 2018 edition. New York, Geneva, Washingtonn D.C. Available at: https://data.unicef.org/wpcontent/uploads/2018/05/JME-2018brochure.pdf

Wawan., \& Dewa. 2011. Teori Pengukuran Pengetahuan, Sikap, Dan Perilaku Manusia. Nuhu Medika

WHO. 1997. Child Growth Indicators and Their Interpretation.

2007. Community-Based Management Of Severe Acute Malnutrition.

Geneve

Zeitlin, M. (2000). Gizi balita di Negara-Negara Berkembang, Peran Pola Asuh Anak : Pemanfaatan Hasil Studi Penyimpangan Positif Untuk Program Gizi. Paper Presented At The Widyakarya Pangan Dan Gizi VII, Jakarta. 